\begin{tabular}{|c|c|c|c|c|c|c|}
\hline \multirow{4}{*}{ Impact Factor: } & ISRA (India) & $=3.117$ & SIS (USA) & $=0.912$ & ICV (Poland) & $=6.630$ \\
\hline & ISI (Dubai, UAE & $=\mathbf{0 . 8 2 9}$ & РИНЦ (Russia) & $=0.156$ & PIF (India) & $=1.940$ \\
\hline & GIF (Australia) & $=0.564$ & ESJI (KZ) & $=5.015$ & IBI (India) & $=4.260$ \\
\hline & JIF & $=1500$ & SUF (Morocc & & & \\
\hline
\end{tabular}

QR - Issue

SOI: $\underline{1.1 / \text { TAS }}$ DOI: $10.15863 /$ TAS

International Scientific Journal Theoretical \& Applied Science

p-ISSN: 2308-4944 (print) e-ISSN: 2409-0085 (online)

Year: 2019 Issue: $01 \quad$ Volume: 69

Published: 19.01.2019 http://T-Science.org

SECTION 2. Applied mathematics. Mathematical modeling.

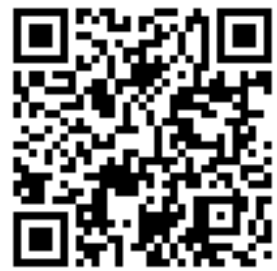

QR - Article

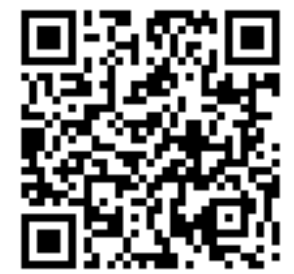

Denis Chemezov

M.Sc.Eng., Corresponding Member of International Academy of Theoretical and Applied Sciences, Lecturer of Vladimir Industrial College, Russian Federation https://orcid.org/0000-0002-2747-552X chemezov-da@yandex.ru

Ilya Filippov Student of Vladimir Industrial College, Russian Federation

Alexandra Strunina
Lecturer of Vladimir Industrial College,
Russian Federation

Irina Pavluhina Lecturer of Vladimir Industrial College, Russian Federation

Maxim Potapov Student of Vladimir Industrial College, Russian Federation

\title{
RESEARCH OF PROPERTIES AND REGIMES OF INCOMPRESSIBLE FLUID FLOW IN A CYLINDRICAL PIPELINE WITH TWO ELBOWS
}

Abstract: Trajectories of water flow under normal conditions at straight and curved sections of a cylindrical pipeline are presented in the article. Changing dependencies of physical, thermal properties and properties of turbulent fluid flow from the trajectory length of the pipeline are obtained. Pressure drop of moving fluid depends on local resistances (bends) and incomplete filling of the cross-section of the pipeline by fluid at the straight section and at an outlet from the second elbow.

Key words: a pipeline, an elbow, a straight section, fluid flow, pressure, velocity.

Language: English

Citation: Chemezov, D., Filippov, I., Strunina, A., Pavluhina, I., \& Potapov, M. (2019). Research of properties and regimes of incompressible fluid flow in a cylindrical pipeline with two elbows. ISJ Theoretical \& Applied Science, 01 (69), 79-84.

Soi: http://s-o-i.org/1.1/TAS-01-69-16 Doi: crossef https://dx.doi.org/10.15863/TAS.2019.01.69.16

\section{Introduction}

Fluid flow in pipelines changes from laminar to transient regime and vice versa. Stable turbulent flow of fluid develops in hydraulic (gas) turbines and similar devices. Transient flow caused by the intensive mixing of moving fluid layers is observed in local hydraulic resistances (elbows, diffusers, confusers and etc.) and at the some distance after them [1 - 10]. Pressure of moving incompressible fluid at a straight section of the pipeline with the length of $1 \mathrm{~m}$ changes up to $20 \%$. Set of changing of hydraulic properties of fluid at these sections of the pipeline is an overall assessment of efficiency of fluid movement over the distance. Observation for a process of fluid flow is difficult, because flow is not visible due to opacity of the pipeline walls. Measurement of hydrodynamic parameters of moving fluid (changing of pressure, temperature, the turbulent flow parameters and etc.) in the pipeline by means of the special devices is the time-consuming process, so the qualitative results of changing of flow and the properties of incompressible fluid along the 


\begin{tabular}{|c|c|c|c|c|c|c|}
\hline \multirow{4}{*}{ Impact Factor: } & ISRA (India) & $=3.117$ & SIS (USA) & $=0.912$ & ICV (Poland) & $=6.630$ \\
\hline & ISI (Dubai, UAE & $=0.829$ & РИНЦ (Russia) & $=0.156$ & PIF (India) & $=1.940$ \\
\hline & GIF (Australia) & $=0.564$ & ESJII (KZ) & $=5.015$ & IBI (India) & $=4.260$ \\
\hline & JIF & $=1.500$ & SJIF (Morocco) & $=5.667$ & & \\
\hline
\end{tabular}

transverse and longitudinal sections of the pipeline with two elbows can be obtained the most effectively by finite element modeling in special computer programs.

\section{Materials and methods}

A computer simulation of the flow process of incompressible fluid (water) in the metal pipeline
(AISI 316L stainless steel) was performed in the Flow Simulation software environment. The solid model of the cylindrical pipeline with two elbows is presented in the Fig. 1. An inlet was accepted on the left side of the pipeline model; an outlet was accepted on the right side.

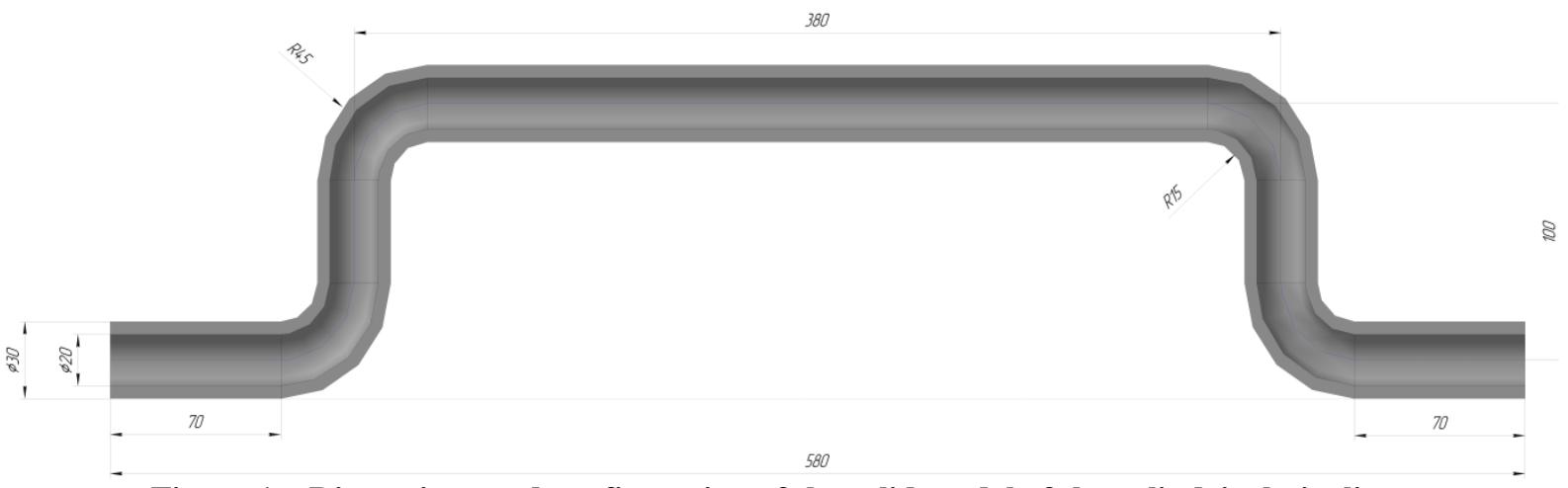

Figure 1 - Dimensions and configuration of the solid model of the cylindrical pipeline.

The following conditions were accepted for performing of the computer simulation:

- initial velocity of fluid flow at the pipeline inlet is $0.7 \mathrm{~m} / \mathrm{s}$;

- initial temperature of fluid and the pipeline material is $293.2 \mathrm{~K}$;

- static pressure is $101325 \mathrm{~Pa}$;

- accounting of fluid cavitation;

- dissolved gas mass fraction is 0.0001 ;

- the outer wall condition is adiabatic wall with roughness of $5 \mu \mathrm{m}$;

- the boundary layer type is turbulent;

- the turbulence intensity and length are $2 \%$ and $3 \cdot 10^{-4} \mathrm{~m}$ respectively.

\section{Results and discussion}

The dependencies of density (A), dynamic pressure (B), dynamic viscosity (C), fluid thermal conductivity (D), Mach number (E), Prandtl number $(F)$, relative pressure $(\mathrm{G})$, specific heat $(\mathrm{H})$, temperature fluid $(\mathrm{I})$, total pressure $(\mathrm{J})$, turbulent dissipation $(\mathrm{K})$, turbulent energy $(\mathrm{L})$, turbulent intensity (M), turbulent length $(\mathrm{N})$, turbulent time $(\mathrm{O})$, turbulent viscosity $(\mathrm{P})$, velocity $(\mathrm{Q})$ and vorticity (R) from the trajectories length of fluid flow in the cylindrical pipeline are presented in the table 1 . The number of fluid flow trajectories located from a center line to a surface of inner wall of the pipeline was accepted 20.

Table 1. The calculated values of the hydrodynamic parameters of fluid flow in the cylindrical pipeline.

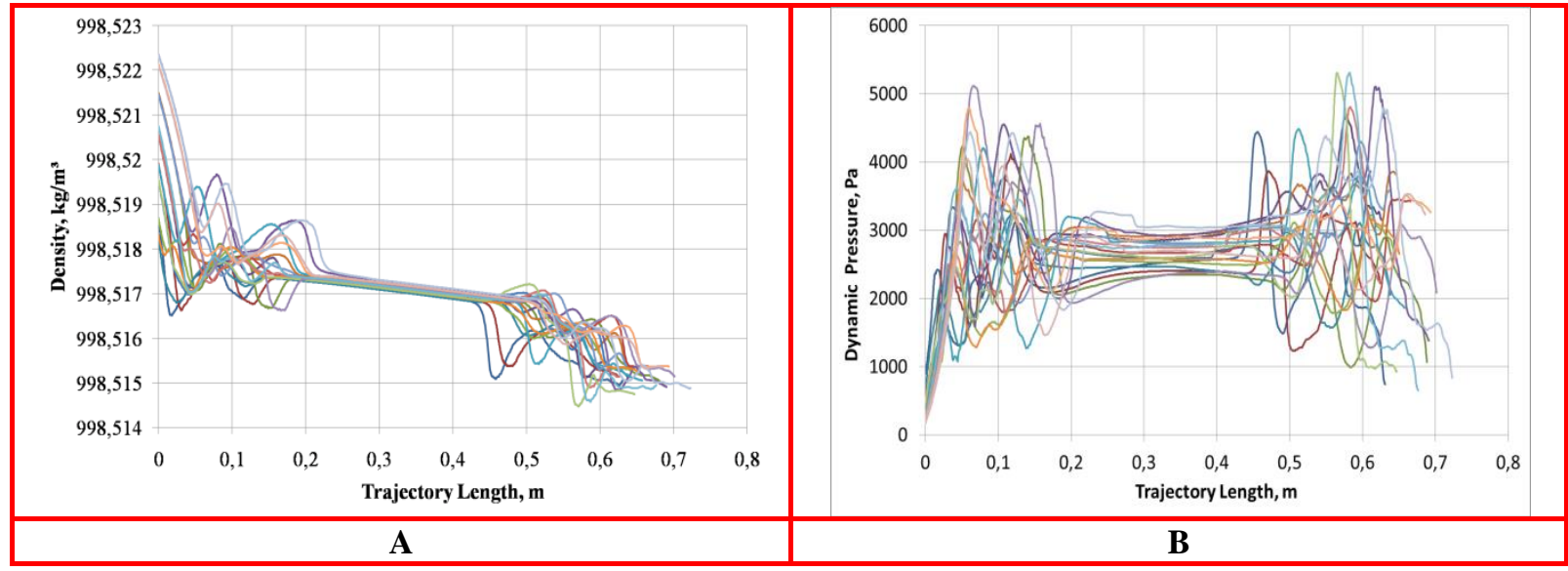




\begin{tabular}{|c|c|c|c|c|c|c|}
\hline \multirow{4}{*}{ Impact Factor: } & ISRA (India) & $=3.117$ & SIS (USA) & $=0.912$ & ICV (Poland) & $=6.630$ \\
\hline & ISI (Dubai, UAE & $=0.829$ & РИНЦ (Russia) & $=0.156$ & PIF (India) & $=1.940$ \\
\hline & GIF (Australia) & $=0.564$ & ESJI (KZ) & $=\mathbf{5 . 0 1 5}$ & IBI (India) & $=4.260$ \\
\hline & JIF & $=1.500$ & SJIF (Morocco) & $=\mathbf{5 . 6 6 7}$ & & \\
\hline
\end{tabular}

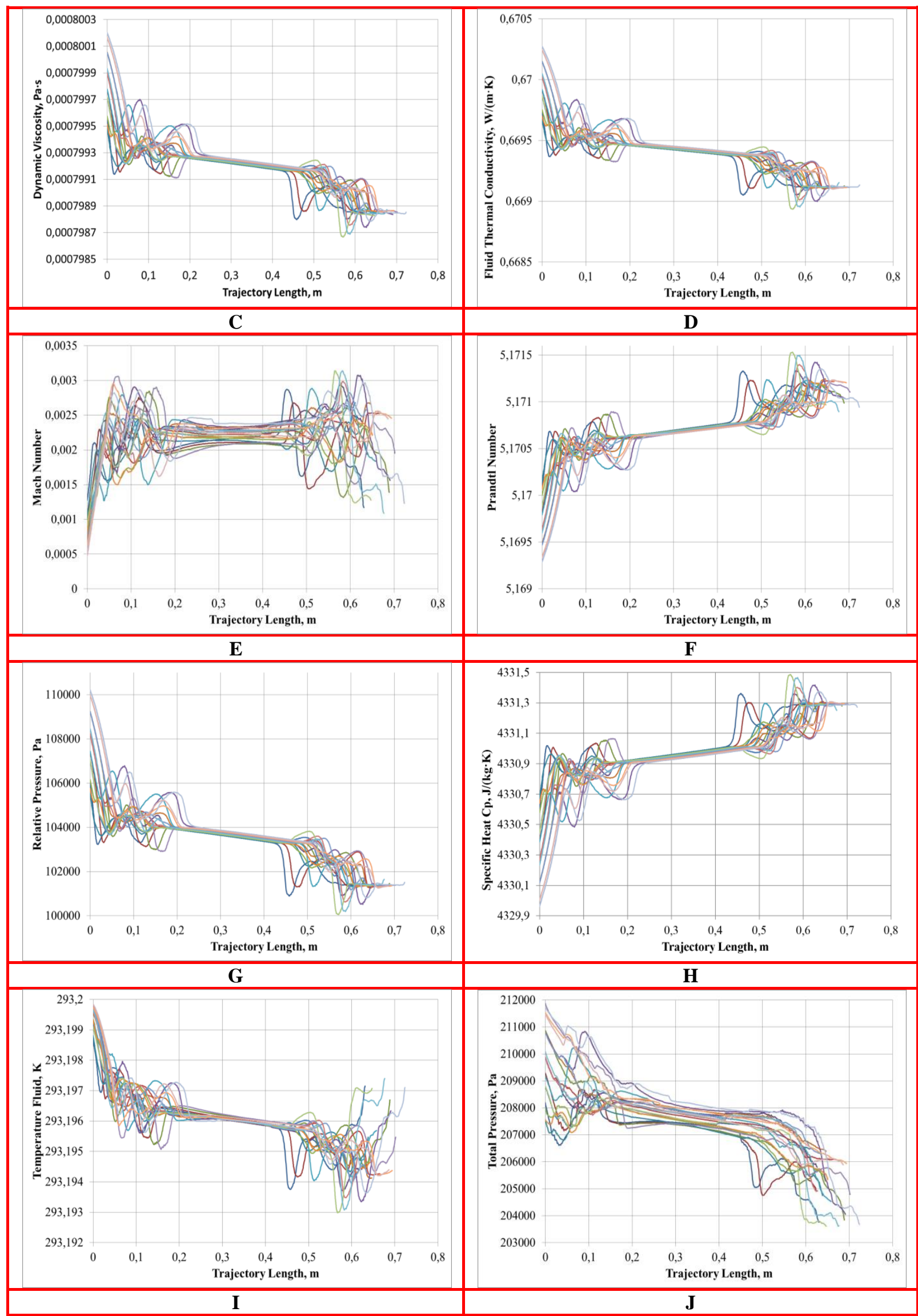




\begin{tabular}{lllllll} 
& ISRA (India) & $\mathbf{3} .117$ & SIS (USA) & $=\mathbf{0 . 9 1 2}$ & ICV (Poland) & $\mathbf{= 6 . 6 3 0}$ \\
Impact Factor: & ISI (Dubai, UAE) $=\mathbf{0 . 8 2 9}$ & PUHL (Russia) $=\mathbf{0 . 1 5 6}$ & PIF (India) & $=\mathbf{1 . 9 4 0}$ \\
GIF (Australia) & $=\mathbf{0 . 5 6 4}$ & ESJI (KZ) & $=\mathbf{5 . 0 1 5}$ & IBI (India) & $\mathbf{4 . 2 6 0}$ \\
& JIF & $=\mathbf{1 . 5 0 0}$ & SJIF (Morocco) & $=\mathbf{5 . 6 6 7}$ & & \\
\hline
\end{tabular}
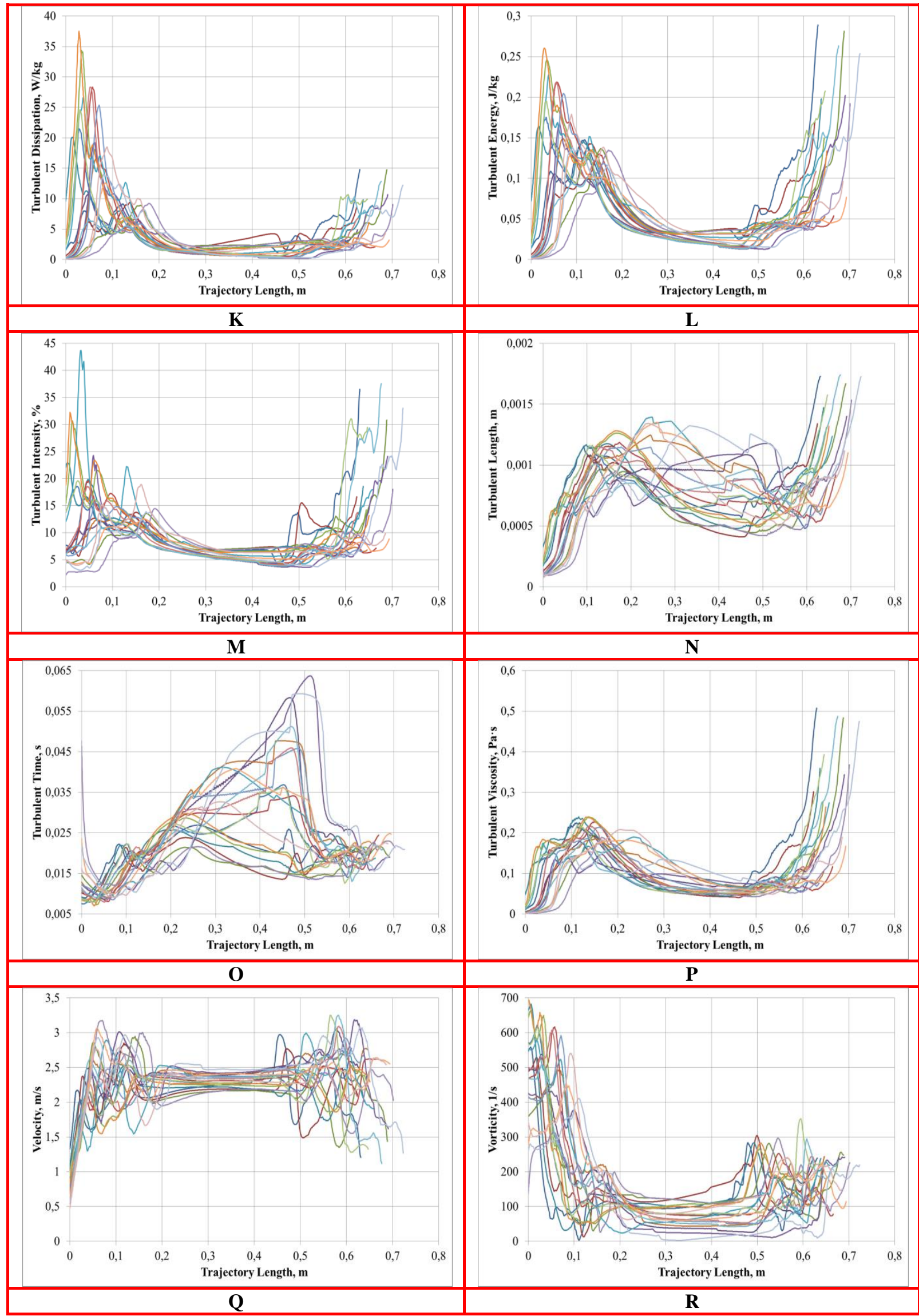


\begin{tabular}{|c|c|c|c|c|c|c|}
\hline \multirow{4}{*}{ Impact Factor: } & ISRA (India) & $=3.117$ & SIS (USA) & $=0.912$ & ICV (Poland) & $=6.630$ \\
\hline & ISI (Dubai, UAE & $=0.829$ & РИНЦ (Russia) & $=0.156$ & PIF (India) & $=1.940$ \\
\hline & GIF (Australia) & $=0.564$ & ESJII (KZ) & $=5.015$ & IBI (India) & $=4.260$ \\
\hline & JIF & $=1.500$ & SJIF (Morocco) & $=5.667$ & & \\
\hline
\end{tabular}

Let us imagine the pipeline configuration as the several sections (from left to right): the inlet and the left elbow; the straight section; the right elbow and the outlet. At analysis of the graphs, it is determined that the mixing of the fluid layers, and, consequently, maximum changing of the hydraulic parameters (except for the some parameters of turbulent flow) occurs in the left and right elbows of the pipeline. Density (by $0.0007 \%$ ), dynamic viscosity (by $0.187 \%$ ), fluid thermal conductivity (by $0.186 \%$ ), relative pressure (by 9.1\%) and total pressure (by $3.77 \%$ ) are constantly decreased at fluid flow through all sections of the cylindrical pipeline. At the same time, Prandtl number (by $0.038 \%$ ) and specific heat of fluid (by $0.037 \%$ ) are constantly increased. Temperature of moving fluid decreases in the left elbow and in the straight section of the pipeline. Some increasing of fluid temperature is observed in the right elbow of the cylindrical pipeline. Dynamic pressure, Mach number and fluid flow velocity in the left and right elbows of the pipeline change almost equally. Fluid flow velocity on average changes by 2 $\mathrm{m} / \mathrm{s}$. Mach number at transition regime of fluid flow reaches the value of 0.003 , at laminar regime this parameter was defined in the range of $0.002 \ldots 0.0025$.
Dynamic pressure increases by 5 times. Turbulent dissipation of moving fluid in the left elbow is 2.5 times as many than in the right elbow of the pipeline. Turbulent energy of moving fluid increases at the inlets of the pipeline elbows. Turbulent intensity of fluid flow in the pipeline elbows increases up to 8 times as compared to pattern of fluid flow in the straight section. Turbulent length reaches the maximum value at the outlet from the right elbow of the pipeline; turbulent time reaches the maximum value at the inlet to the right elbow. Turbulent viscosity of moving fluid increases in the pipeline elbows and decreases in the straight section as compared to dynamic viscosity. Maximum vorticity of fluid flows was determined at the inlet to the right elbow of the pipeline. Vorticity of fluid flows is reduced by $2-2.5$ times in the right elbow. Turbulent viscosity of fluid increases by $0.5 \mathrm{~Pa} \cdot \mathrm{s}$. Vortex crosses pressure opening. Inlet flow/outlet flow $=0.365544$.

The contours of flow velocity of water in all sections of the cylindrical pipeline model are presented in the longitudinal section (the Fig. 2).

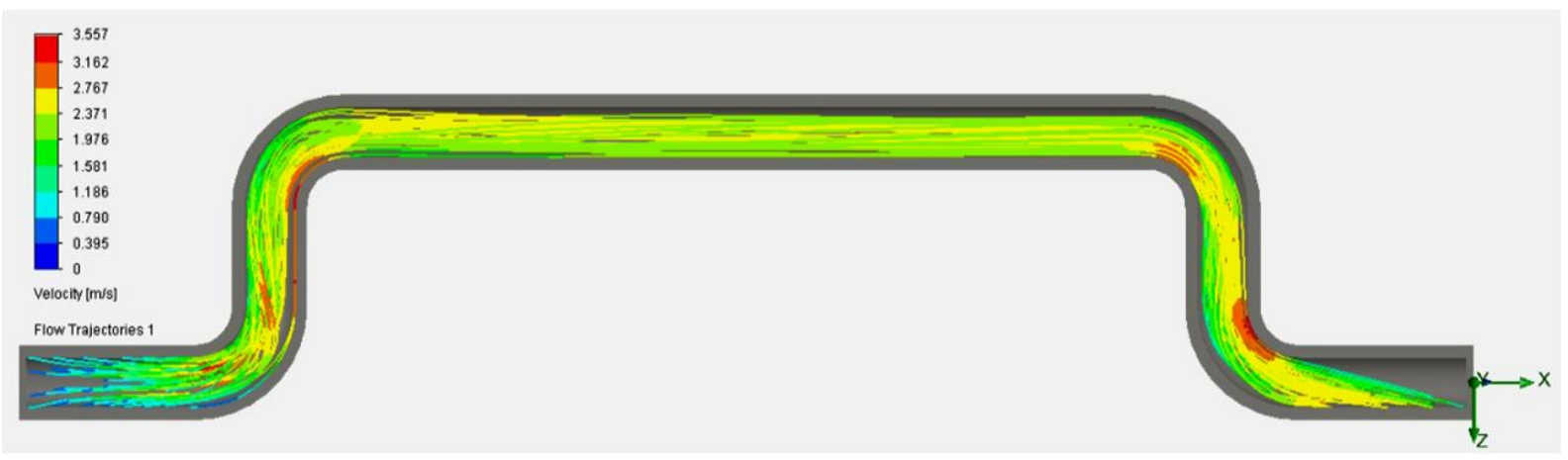

Figure 2 - The contours of water flow velocity in the pipeline model with two elbows.

Flow velocity of fluid increases by 5 times at inner and outer radii of the pipeline elbow as compared to initial velocity. Uniform fluid flow is observed at the cylindrical section of the pipeline. Fluid fills the cross-section of the pipeline by $85 \%$ after the left elbow. Fluid, moving from the right elbow, has a flow angle which does not allow to completely fill the cylindrical section of the pipeline for some time.

\section{Conclusion}

Stable laminar flow of fluid is observed at $2 / 3$ of the length of the straight section of the pipeline to the second elbow. Turbulent fluid flow develops in the left and right elbows of the pipeline. Turbulent intensity of fluid flow in the left and right elbows is same. Filling of the cross-section of the straight section after the first elbow of the pipeline is $85 \%$, and filling after the second elbow is not more than $50 \%$. This is due to decreasing of fluid pressure caused by the layers mixing in the left elbow. 


\begin{tabular}{|c|c|c|c|c|c|c|}
\hline \multirow{4}{*}{ Impact Factor: } & ISRA (India) & $=3.117$ & SIS (USA) & $=0.912$ & ICV (Poland) & $=6.630$ \\
\hline & ISI (Dubai, UAE & $=0.829$ & РИНЦ (Russia) & $=0.156$ & PIF (India) & $=1.940$ \\
\hline & GIF (Australia) & $=0.564$ & ESJI (KZ) & $=5.015$ & IBI (India) & $=4.260$ \\
\hline & JIF & $=1.500$ & SJIF (Morocco) & $=5.667$ & & \\
\hline
\end{tabular}

\section{References:}

1. Chemezov, D. A. (2015). Hydrodynamic characteristics of water flow in straight and curved sections of a pipeline. Modern materials, equipment and technology: Materials of the $4^{\text {th }}$ International scientific and practical conference, South-West State University, CJSC «University book», Kursk, pp.468 - 471 .

2. Chemezov, D. A., Tyurina, S. I., Bayakina, A. V., \& Goremykin, V. V. (2014). Fluid transients flow in piping elbow. ISJ Theoretical \& Applied Science, 12 (20), 4-8.

3. Chemezov, D. (2017). Calculation of pressure losses of liquid at a cylindrical straight pipeline section. ISJ Theoretical \& Applied Science, 12 (56), $19-22$

4. Chemezov, D., \& Palev, N. (2016). Analytical models of the turbulent fluid flow in a circular pipe. ISJ Theoretical \& Applied Science, 09 (41), $77-84$.

5. Chemezov, D., et al. (2018). Parameters calculation of turbulent fluid flow in a pipe of a circular cross section. International Journal of Innovation Engineering and Science Research, vol. 2, issue 6, 38-42.
6. Chemezov, D., \& Bayakina, A. (2016). The simulation of the fluid flow on the inner wall of the circular pipe. ISJ Theoretical \& Applied Science, 10 (42), 1-3.

7. Chemezov, D. A., Kukhar', N. A., \& Kovalenko, N. O. (2015). Fluid flow in a steel tubular coil (distribution of pressure gradient). Modern tool systems, information technologies and innovations: Collection of scientific works of the XII ${ }^{\text {th }}$ International scientific and practical conference, Volume 4, South-West State University, Kursk, $243-247$.

8. Chemezov, D. (2016). The character of the fluid flow in the pipelines with the local hydraulic resistances. ISJ Theoretical \& Applied Science, 12 (44), 62-68.

9. Tu, S.-W., \& Ramaprian, B. R. (1983). Fully developed periodic turbulent pipe flow in a tube. J. Fluid Mech. 137, 31-58.

10. Liu, H., Zong, Q., Lv, H., \& Jin, J. (2017). Analytical equation for outflow along the flow in a perforated fluid distribution pipe. PLoS ONE, 12(10), 1-18. 